\title{
Assessment of Quality of Peda Samples Sold in Kamareddy District - A Case Study
}

\author{
Srikanth Keerthi ${ }^{{ }^{*}}$, Vyshnavi Manthani ${ }^{2}$ and G. Swarnalatha ${ }^{3}$
}

${ }^{1}$ Department of Dairy Technology, ${ }^{2}$ Department of Dairy Microbiology, ${ }^{3}$ Department of Dairy Chemistry, College of Dairy Technology, PVNR TVU, Kamareddy, India

*Corresponding author

\section{A B S T R A C T}

\section{Keywords}

Peda, Chemical, Microbial, Sensory characteristics, Market samples

Article Info

Accepted:

15 January 2018

Available Online:

10 February 2018
Present study was carried out to assess the chemical composition, microbial count and sensory characteristics of laboratory and market peda samples collected from local vendors of Kamareddy district. A significant variation in moisture, fat, protein, ash, total sugar and acidity content ranged from 14.430 to $16.227 \%, 14.057$ to $17.837 \%, 14.193$ to16.807\%, 2.907 to $3.117 \%, 45.087$ to $51.357 \%$ has been observed. The moisture, fat and protein content were higher and total sugar, acidity was lower in laboratory samples when compared with market samples. The Total plate count, Yeast and mold and Coliform count showed highly significant difference $(\mathrm{P}<0.01)$ among laboratory $\left(\mathrm{T}_{0}\right)$ sample when compared with market peda samples. The coliform count was nil in $\mathrm{T}_{0}$. In sensory characteristics viz. color ad appearance, body and texture, flavor, sweetness and overall acceptability showed significant $(\mathrm{P}<0.01)$ difference between peda samples. Therefore it is concluded laboratory samples were superior to Market samples in all aspects.

\section{Introduction}

India produces about 155.5 million tons of milk annually, out of which about 50-55 \% of milk produced is being converted into variety of traditional Indian dairy products of which $6.5 \%$ of milk is used for manufacture of khoa mostly in private and unorganized sector (Prasad et al., 2012 and Jadhav et al., 2011).

Traditional dairy products (TDP) and sweets are an integral part of Indian heritage and have great social, religious, cultural, medicinal, and economic significance. They have been developed with the culinary skills of home makers and sweet makers (Halwais), over a long epoch (Gotarne et al., 2015).

Khoa is a heat desiccated Indian dairy product used as a base material for a variety of sweetmeats like burfi, peda, gulabjamun etc. Pedais an indigenous khoa based heat desiccate milk sweet prepared by heating mixer of khoa and sugar with addition of natural and/ or artificial color and flavor until the desired characteristics texture and flavor develops (Kavita et al., 2015). Buffalo milk is preferred over cow and goat milks for preparation of khoa based sweets (peda, kalakand etc), because it gives soft and uniform body with smooth, compact and homogeneous texture to 
the finished product (Kamle et al., 2015). The consumption of TDP is likely to grow at an annual growth rate of more than 20 per cent. The manufacture of peda is mostly restricted to halwais. Since peda has lower moisture content it has abetter shelf life. Peda is whitish yellow in color and has a coarse grainy texture. Its quality is determined by chemical composition, body and texture, appearance and microbial quality (Gavhane et al., 2014). Therefore the present study was thus carried out to evaluate the chemical, microbial and sensory qualities of peda samples collected from Kamareddy city.

\section{Materials and Methods}

\section{Collection of raw material}

The whole fresh and clean buffalo milk was procured from local chilling centre, kamareddy. Good quality sugar was obtained from the local market.

For standardization of buffalo milk (fat $6 \%$ and SNF 9\%) Nandini butter and spray dried Nestle skim milk powder were used. The low density polyethylene packaging material was purchased from local market.

\section{Preparation of laboratory peda}

Laboratory peda $\left(\mathrm{T}_{0}\right)$ was prepared from Standardized Buffalo milk (6\% fat and 9\% SNF). Milk was concentrated by heating and continuous stirring, upto $67 \%$ total solids for making khoa. Khoa was then kept for $15 \mathrm{~min}$ and cooled to $25 \pm 3^{\circ} \mathrm{C}$. Khoa and sugar (30\%) were taken in a nonstick pan and heated at $90^{\circ} \mathrm{C}$ till pat formation with continuous stirring and kneading at $50^{\circ} \mathrm{C}$ till the dough become suitable to make peda. Dough was portioned and converted into round balls by rolling between the palms and final shape was given to peda by pressing in dies.

\section{Collection of market samples}

The market peda samples were collected within two to three hours of their preparations from popular sweet shops of Kamareddy city and packed in cardboard boxes of rectangular shape $\left(10 \times 12 \mathrm{~cm}^{2}\right)$. The cardboard boxes were packed and sealed in polyethylene bags to prevent gain or loss of moisture during transport. The samples were tempered to room temperature before analysis of different quality parameters. They were designated as $\mathrm{T}_{1}, \mathrm{~T}_{2}, \mathrm{~T}_{3}$ and $\mathrm{T}_{4}$ to maintain the privacy of the source.

\section{Chemical analysis}

The Laboratory and Market peda samples were chemically analyzed for moisture (IS: 2785, 1964), fat (IS: 1224, Part II, 1977), acidity (IS, 18 Part (XI) (1981), protein (Meneffee and Overman, 1940), ash (A.O.A.C 1975), total carbohydrate content was obtained by difference method.

\section{Microbial analysis}

Microbiological parameters of Laboratory and Market peda samples were determined by using standard procedure for Total plate count by method cited in (ISI: 5402, 1969) by using Tryptone Dextrose Agar medium, Yeast and Mould count by method cited in (ISI: 5403, 1969) by using Potato Glucose Agar medium and Coliform count by (Chalmers, 1955) by Mac Conkey's broth medium.

After incubation at $37^{\circ} \mathrm{C}$ for $24 \mathrm{hrs}$, the microorganisms were identified on the basis of colony characteristics. Results were expressed as Cfu per gm of sample.

\section{Sensory evaluation}

Sensory evaluation of Laboratory and Market peda were carried out by a panel of five 
judges selected from the faculty of college of Dairy Technology by using " 9 point Hedonic scale" developed by Gupta (1976).

\section{Statistical analysis}

The data were subjected to analysis of variance (ANOVA), using by completely randomized design for chemical, microbial and sensory analysis was computed as described by Steel and Torrie, (1980).

\section{Results and Discussion}

The Results obtained from the present study on chemical, microbiological and sensory characteristics of freshly prepared laboratory and market samples of peda are depicted in Tables 1-3.

\section{Chemical composition}

The results of three replicates were chemically analyzed and compared statistically among the different samples as presented in Table 1.

\section{Moisture content}

The moisture content of laboratory peda sample $\left(\mathrm{T}_{0}\right) 16.227$ was slightly higher than that of the market samples viz., $\mathrm{T}_{1}, \mathrm{~T}_{2}, \mathrm{~T}_{3}$ and $\mathrm{T}_{4}$ ranged from $14.430\left(\mathrm{~T}_{4}\right)$ to $15.917\left(\mathrm{~T}_{2}\right)$ as shown in Table 1. The standard of khoa under the Prevention of Food Adulteration Act (1954) required that it should not contain more than: $28.0 \%$ moisture. However, the results of present findings are accordance with earlier workers Dasturand Lakhani (1971) supported this standard after examining vendor's khoa in Poona city. The dealers of khoa however complained that, such a low moisture level was not practicable in the trade since goodquality sweets could not be prepared from such an over-desiccated product (Rajorhia and Srinivasan 1974).Similar observations were also made by Sharma et al., (2012), who reported that the moisture content of milk cake was slightly higher in control samples $26.70 \pm$ $1.61 \%$ than market samples as $23.60 \pm 3.35$ and $25.90 \pm 6.97 \%$.

It could be observed from the Table that the moisture content of all peda samples were differed significantly $(\mathrm{P}<0.01)$. The variation in the moisture content might be mainly due to the difference in method of manufacture, extent of desiccation, amount of sugar added, difference in chemical composition of base material used. The present findings are accordance with Kavita et al., (2015), who reported that there is significant difference between the laboratory and market peda samples of Raipur city and also Patel et al., (2006), analyzed five peda samples from different cities of Gujarat state for chemical attributes and reported significant differences in moisture content.

\section{Fat content}

The fat content of market peda samples $\mathrm{T}_{1}, \mathrm{~T}_{2}$, $\mathrm{T}_{3}$, and $\mathrm{T}_{4}$, ranged from $14.057\left(\mathrm{~T}_{4}\right)$ to 16.183 $\left(\mathrm{T}_{2}\right)$ and laboratory peda sample $17.837\left(\mathrm{~T}_{0}\right)$ was found to be highly significant $(\mathrm{P}<0.01)$ as presented in Table 1 . The difference in the fat content of peda samples might be attributed to the variation in the type of milk used (buffalo/cow) and their fat content, amount of sugar added and duration of desiccation. The present study was in alignment with Kavita $e t$ al., (2015) concluded that there is significant difference was found between the laboratory and market made peda samples, Sharma and Zariwal (1978) and Patel (1996), who also reported large variation in the fat content (14.92 to $23.92 \%$ ) of market samples of peda.

\section{Protein, ash content}

The Protein and ash content was also found to be highly significant $(\mathrm{P}<0.01)$ among the treatments. The highest protein content was 
observed for laboratory peda sample $\left(\mathrm{T}_{0}\right)$ 16.807 and market peda samples varied from $14.193\left(\mathrm{~T}_{1}\right)$ to $15.917\left(\mathrm{~T}_{2}\right)$.

The Ash content of market peda samples was higher for the $\mathrm{T}_{2}$ and $\mathrm{T} 4$ (3.117) when compared with other samples $\mathrm{T}_{1}$ (2.909) and $\mathrm{T}_{3}$ (2.757) and laboratory peda sample 3.043 $\left(\mathrm{T}_{0}\right)$. Our findings correlate with the reports of Rajorhia and Srinivasan (1979), who studied that the lactose, milk proteins and ash contents in khoa samples also showed fairly wide variations. The type of milk used, extent of desiccation and addition of adulterants would cause such disparity.

\section{Total sugars}

The Total sugars of market peda samples $\mathrm{T}_{1}$, $\mathrm{T}_{2}, \mathrm{~T}_{3}$ and $\mathrm{T}_{4}$, ranged from $51.357 \%\left(\mathrm{~T}_{4}\right)$ to $47.787 \%\left(\mathrm{~T}_{2}\right)$ and laboratory peda sample has $45.087 \%\left(\mathrm{~T}_{0}\right)$, highly significant difference $(\mathrm{P}<0.01)$ was observed among the samples but $\mathrm{T}_{1}$ and $\mathrm{T}_{3}$ at par with each other as presented in Table 2.

The significant difference in the Total sugars of peda samples could be due to the amount of sugar added and time of desiccation, composition of base material used during its preparation. Similar kind of relationship was observed in the preparation of milk cake by earlierworkers Sharma et al., (2012), who observed that the sucrose content of market samples as 29.34 in zone I and 25.40 in zone II was higher than 24.52 in control samples which corroborate our observations.

\section{Acidity}

The acidity of market peda samples $\mathrm{T}_{1}, \mathrm{~T}_{2}, \mathrm{~T}_{3}$ and $\mathrm{T}_{4}$, ranged from $0.633 \%\left(\mathrm{~T}_{2}\right)$ to $0.540 \%$ $\left(\mathrm{T}_{4}\right)$ was higher than laboratory peda sample $0.50 \%\left(\mathrm{~T}_{0}\right)$. Highly significant difference $(\mathrm{P}<0.01)$ was observed among the samples but $\mathrm{T}_{1}$ and $\mathrm{T}_{2}$ at par with each other as depicted in
Table 2. The data found to be close to the research work conducted by Kavita et al., (2015), also found significant difference in the acidity of peda samples might be the result of use of either milk with different acidity or amount of sugar added and degree of heat treatment used during its preparation.

\section{Microbial analysis}

The Total Plate count, Yeast and mold, and Coliform count were done for laboratory and market peda samples and the results are presented in Table 2 .

TheTotal plate count, Yeast and mold and Coliform count of laboratory peda sample $3.240,3.410$ and nil respectively $\left(\mathrm{T}_{0}\right)$ was lower than the market peda samples $\mathrm{T}_{1}, \mathrm{~T}_{2}, \mathrm{~T}_{3}$, and $\mathrm{T}_{4}$ were 4.187 to $4.860,4.127$ to 3.777 and 2.110 to 1.930 respectively. Highly significant difference $(\mathrm{P}<0.01)$ was found among the treatments. The difference in the TPC of peda samples might be mainly due to unhygienic conditions prevailing during manufacture and quality of raw material used during preparation of peda.

Spoilage of dairy products by molds is of frequent accurance in India is due to the prevailing tropical climate and high humidity. Since the mold spores are transmitted through air, they are ubiquitous in nature Karthikeyan, $\mathrm{N}$ and Pandiyan, C (2012).

The difference in the coliform count of peda samples could be due to uncleaned hands of workers, poor quality of milk, unhygienic conditions of manufacturing unit, inferior quality of material used, water supplied for washing the utensils and post processing contamination. Our findings were correlated with the reports of Kumar and Sinha (1989), Grewal and Tiwari (1990) and Kulshresthra (1990). 
Table.1 Average chemical composition of laboratory and market made peda samples

\begin{tabular}{|r|l|l|l|l|l|l|}
\hline Treatments & Moisture & Fat & \multicolumn{1}{|c|}{ Protein } & Ash & Total Sugars & Acidity \\
\hline $\mathrm{T}_{0}$ & $16.227^{\mathrm{a}}$ & $17.837^{\mathrm{a}}$ & $16.807^{\mathrm{a}}$ & $3.043^{\mathrm{b}}$ & $45.087^{\mathrm{d}}$ & $0.500^{\mathrm{d}}$ \\
\hline $\mathrm{T}_{1}$ & $15.790^{\mathrm{bc}}$ & $15.260^{\mathrm{c}}$ & $14.193^{\mathrm{e}}$ & $2.907^{\mathrm{c}}$ & $50.723^{\mathrm{bc}}$ & $0.563^{\mathrm{c}}$ \\
\hline $\mathrm{T}_{2}$ & $15.917^{\mathrm{b}}$ & $16.183^{\mathrm{b}}$ & $15.917^{\mathrm{b}}$ & $3.117^{\mathrm{a}}$ & $47.787^{\mathrm{c}}$ & $0.540^{\mathrm{cd}}$ \\
\hline $\mathrm{T}_{3}$ & $14.830^{\mathrm{c}}$ & $15.100^{\mathrm{d}}$ & $15.373^{\mathrm{d}}$ & $2.757^{\mathrm{d}}$ & $50.777^{\mathrm{b}}$ & $0.603^{\mathrm{b}}$ \\
\hline $\mathrm{T}_{4}$ & $14.430^{\mathrm{d}}$ & $14.057^{\mathrm{e}}$ & $15.763^{\mathrm{c}}$ & $3.117^{\mathrm{a}}$ & $51.357^{\mathrm{a}}$ & $0.633^{\mathrm{a}}$ \\
\hline F-Values & $322.132^{* *}$ & $27027.746^{* *}$ & $14297.341^{* *}$ & $63.723^{* *}$ & $2249.875^{* *}$ & $41.051^{* *}$ \\
\hline SE $(\mathbf{m})$ & 0.0427 & 0.0086 & 0.0079 & 0.0194 & 0.0561 & 0.0082 \\
\hline CD $(\mathbf{5 \%})$ & 0.13 & 0.03 & 0.03 & 0.06 & 0.18 & 0.03 \\
\hline
\end{tabular}

** Highly significant $\mathrm{P}(<0.01)$

Table.2 Average microbial count of laboratory and market made peda samples

\begin{tabular}{|c|c|c|c|}
\hline Treatments & $\begin{array}{l}\text { Total plate count } \\
\left(\log _{10} . \mathrm{cfu} / \mathrm{g}\right)\end{array}$ & $\begin{array}{l}\text { Yeast and mould } \\
\left.\text { count( } \log _{10} . \mathrm{cfu} / \mathrm{g}\right)\end{array}$ & $\begin{array}{l}\text { Coliforms } \\
\left(\log _{10} . c f u / g\right)\end{array}$ \\
\hline$T_{0}$ & $3.240^{\mathrm{e}}$ & $3.410^{\mathrm{e}}$ & $0.000^{\mathrm{e}}$ \\
\hline $\mathrm{T}_{1}$ & $4.187^{\mathrm{a}}$ & $3.777^{\mathrm{d}}$ & $1.930^{\mathrm{d}}$ \\
\hline$T_{2}$ & $3.860^{\mathrm{d}}$ & $4.070^{\mathrm{b}}$ & $2.020^{c}$ \\
\hline$T_{3}$ & $4.107^{c}$ & $4.030^{c}$ & $2.110^{\mathrm{a}}$ \\
\hline$\overline{T_{4}}$ & $4.163^{b}$ & $4.127^{\mathrm{a}}$ & $2.053^{\mathrm{b}}$ \\
\hline F-Values & $3379.307^{* *}$ & $789.360^{* *}$ & $13292.589^{* *}$ \\
\hline $\mathrm{SE}(\mathrm{m})$ & 0.0068 & 0.0105 & 0.0079 \\
\hline CD (5\%) & 0.02 & 0.03 & 0.02 \\
\hline
\end{tabular}

** Highly significant $\mathrm{P}(<0.01)$

Table.3 Average sensory scores of laboratory and market made peda samples

\begin{tabular}{|c|c|c|c|c|c|}
\hline Treatments & $\begin{array}{c}\text { Colour and } \\
\text { appearance }\end{array}$ & $\begin{array}{c}\text { Body and } \\
\text { texture }\end{array}$ & Flavour & Sweetness & $\begin{array}{c}\text { Overall } \\
\text { acceptability }\end{array}$ \\
\hline $\mathrm{T}_{0}$ & $8.990^{\mathrm{a}}$ & $8.750^{\mathrm{a}}$ & $8.703^{\mathrm{a}}$ & $8.680^{\mathrm{a}}$ & $8.780^{\mathrm{a}}$ \\
\hline $\mathrm{T}_{1}$ & $8.070^{\mathrm{e}}$ & $8.183^{\mathrm{c}}$ & $7.963^{\mathrm{d}}$ & $8.173^{\mathrm{c}}$ & $8.100^{\mathrm{c}}$ \\
\hline $\mathrm{T}_{2}$ & $8.717^{\mathrm{b}}$ & $8.270^{\mathrm{b}}$ & $8.127^{\mathrm{b}}$ & $8.227^{\mathrm{b}}$ & $8.337^{\mathrm{b}}$ \\
\hline $\mathrm{T}_{3}$ & $8.283^{\mathrm{c}}$ & $8.017^{\mathrm{d}}$ & $8.097^{\mathrm{c}}$ & $7.960^{\mathrm{e}}$ & $8.087^{\mathrm{cd}}$ \\
\hline $\mathrm{T}_{4}$ & $8.137^{\mathrm{d}}$ & $7.933^{\mathrm{e}}$ & $7.833^{\mathrm{e}}$ & $8.067^{\mathrm{d}}$ & $7.993^{\mathrm{d}}$ \\
\hline $\mathrm{F}-$ Values & $1486.768^{* *}$ & $636.897^{* *}$ & $1140.412^{* *}$ & $394.000^{* *}$ & $2993.573^{* *}$ \\
\hline $\mathrm{SE}(\mathbf{m})$ & 0.0103 & 0.0127 & 0.0099 & 0.0139 & 0.0058 \\
\hline $\mathrm{CD}(\mathbf{5} \%)$ & 0.03 & 0.04 & 0.03 & 0.04 & 0.02 \\
\hline
\end{tabular}

** Highly significant $\mathrm{P}(<0.01)$ 
Higher bacterial contamination was found in all market samples when compared with laboratory sample. This can be attributed mainly lack of hygienic practices followed during manufacture of product. However considering the impact of consumption of such contaminated products on public health, the HACCP should be applied during the manufacturing process. The analysis from raw material to final product indicate that, though microbiological quality of khoa may be satisfactory at the time of production, it deteriorated by the time it is available for sale in the market (Bhat et al., 2000)

Therefore observing proper hygienic conditions, like thorough washing of hands by food handlers, using clean utensils, etc. could reduce the chances of contamination to a greater extent. The application of HACCP would yield the desired result of improving the safety of food. However adequate education, awareness programs and extension programs on the subject needs to be undertaken and training programs organized for food handlers so that the health of the consumers is not at risk (Godbole et al., 2013).

\section{Sensory characteristics}

The sensory scores for laboratory and market peda samples are represented in Table 3.

\section{Colour and appearance}

Color and appearance score of market and laboratory peda samples $\mathrm{T}_{1}, \mathrm{~T}_{2}, \mathrm{~T}_{3}$ and $\mathrm{T}_{4}$ ranged from 8.717 to 8.070 and $\mathrm{T}_{0} 8.990$ out of 9 point hedonic scale. The mean color \& appearance value differed significantly $(\mathrm{P}<0.01)$ among samples. Difference in the color \& appearance score might be due to wide variation in raw material, amount of sugar added (during heat treatment reaction between sugar and amino acid produce maillard browning), method (direct \& indirect) and duration of heat treatment used for manufacture of peda. Sharma et al., (2001) recorded that increase in fat percentage in khoa resulted in improvement in its color.

\section{Body and Texture:}

The mean score for body and texture of laboratory and market peda samples varied highly significant $(\mathrm{P}<0.01)$. The values derived from the study ranged from $8.270\left(\mathrm{~T}_{1}\right)$ to 7.933 $\left(\mathrm{T}_{4}\right)$ for market samples and laboratory peda $\left(T_{0}\right)$ has 8.750. It might be due to wide variation in chemical composition particularly fat and sugar levels. These findings agreed with the result of Londhe and Pal (2007), who reported that significant effect on the body and texture score of brown peda with increase in the level of fat in milk and sugar, but to a certain extent and Kavita et al., (2015), who also concluded that there is highly significant difference among all the samples.

\section{Flavour}

The Laboratory peda $8.703 \quad\left(\mathrm{~T}_{0}\right)$ showed significant $(\mathrm{P}<0.01)$ variations among the market samples $8.127\left(\mathrm{~T}_{2}\right)$ to $7.833\left(\mathrm{~T}_{4}\right)$. The highest flavor score were obtained for laboratory peda sample which might be due to the higher fat content. These finding are supported by Reddy (1985), who reported that an increase in flavor score of plain peda with the increase in fat content.

\section{Sweetness}

The average score for sweetness varied significantly $(\mathrm{P}<0.01)$ among the samples. The market peda samples $\mathrm{T}_{1}, \mathrm{~T}_{2}, \mathrm{~T}_{3}$ and $\mathrm{T}_{4}$, ranged from $8.227\left(\mathrm{~T}_{2}\right)$ to $7.960\left(\mathrm{~T}_{3}\right)$ and Laboratory peda (T0) has 8.680. The mean sweetness value was highly significantly among the samples. The highest sweetness in this peda samples might be and time of desiccation, composition of base material. The reports also suggested by Desale et al., (2007) studied the effect of compositional variables on the quality of peda. Their findings suggest that maximum sensory scores were obtained for the peda containing $30 \%$ sugar, $15 \%$ moisture and $25 \%$ fat. In current findings acceptable sensory quality for sweetness was obtained for all types of peda. 


\section{Overall acceptability}

The values obtained for market peda samples $\mathrm{T}_{1}, \mathrm{~T}_{2}, \mathrm{~T}_{3}, \mathrm{~T}_{4}$, ranged from $8.337\left(\mathrm{~T}_{2}\right)$ to 7.993 $\left(\mathrm{T}_{4}\right)$ and Laboratory peda has $8.780\left(\mathrm{~T}_{0}\right)$. The mean overall acceptability significantly differed $(\mathrm{P}<0.01)$ among the samples but $\mathrm{T}_{1}$ and $\mathrm{T}_{3}$ were at par with each other. Difference in the overall acceptability might be due to wide variation in color \& appearance, body \& texture, flavor, Sweetness and also variation in chemical composition of market and laboratory peda samples.

A wide variation was observed among laboratory and market peda samples. It is generally found that halwa is prepared the samples of product from admixed milk of low quality or it may be due to the variation in their method of preparation and varying levels of sugar and moisture content.

It is recommended to local vendors should keep in view the public health importance of consumer; the strict hygienic preventive measures should be practiced during pre and post-preparation handling, storage and marketing of the finished products to reduce the microbial load in the finished products, so as to increase quality of the product. It is concluded from present findings that laboratory samples were Superior in all respect of chemical, microbial and sensory quality to that of market Samples.

\section{Acknowledgement}

The authors are highly thankful to the Head and staff of Department of Dairy Technology, Dairy Microbiology and Dairy Chemistry, College of Dairy Technology, Kamareddy, for providing laboratory and other facilities for this research work.

\section{References}

AOAC (1975) Official Methods of Analysis of the Association of Official Analytical Chemists (Pub. Association of Official Analytical Chemists, Washington, USA).
Bhat, R.V., Rao V.S., Lingerkar, K., 2000.Application of hazard analysis and critical control point for improvement of quality of processed foods. ICMR bulletin. 30(5).

Chalmers, C. H. (1955). Bacteria in Relation to Milk Supply (Edward Arnold, publisher Ltd. London) $4^{\text {th }}$ edition.

Dastur, N.N. and Lakhani, AG. (1971). Chemical composition of Khoa. Indian J. Dairy Sci. 24: 223.

Desale, R. J.; Khedhar, J. N.; Narawade, V. E. and Bhosale, D. N. (2007). Effect of processing and compositional variables on quality of peda. Souvenir: Int Conf. Traditional Dairy Foods, National Dairy Research Institute, Karnal. pp: 109.

Gavhane, M.S., Kamble, N.S., Desale, R.J., Ghule, B.K. and Mule, P.R. (2014). Studies on preparation of peda with ginger powder. Int J. Food Agri Vet Sci.4 (2): 64-68.

Godbole, Suchitra, Pranoti Dabholkar and Shyamashri Mallik. (2013). Evaluation of bacteriological quality of khoa Samples sold in Nagpur city (Maharashtra)-A Case study. J. Global Bio Sci. 2(2): 49-52.

Gotarne, R.R., Londhe, G.K and Korake, R.L. (2015). Optimization of levels of date powder and sugar in brown Dates-peda by response surface methodology. Animal science reporter, 9(3): 95-104.

Grewal, J.S. and Tiwari, R.P. (1990). Microbiological quality of rasamalai. $J$. Food Sci and Technol.27:178-179.

Gupta, SA. (1976).Sensory evaluation of food industry. Indian Dairyman 28(8): 293295.

ISI (1969) IS: 5402, IndianStandard Method for Plate Count of Bacteria in Food Stuffs (Manak Bhavan, New Delhi-1).

ISI (1969) IS: 5403, Indian Standard Method for Yeast and Mould Count in Food Stuffs (Manak Bhavan, New Delhi-1).

ISI: 1224 (Part II) (1977) Determination of Fat by Gerbers Method (Part II) Indian Standard Institution (Manak Bhavan, New Delhi). 
ISI: 18 Part (XI) (1981) Hand book of food analysis. Analysis of Dairy products. New Delhi: Bureau of Indian Standards.

ISI: 2785 (1964) Specification for Ice-Cream (Indian Standard Institution, Manak Bhavan, New Delhi.

Jadhav, M.V., Sakhale, B.K., Pawar, V.D., Solanki, S.G., and Agarkar, B.S. (2011). Studies on effect of preservatives on keeping quality of khoa. Food Sci Res J. 2(1): 4-7.

Karthikeyan N and Pandiyan C. (2013).Microbial quality of Khoa and Khoa based milk sweets from different sources. Int Food Res J. 20(3): 14431447.

Kavita Banjare, Manikant Kumar, Goel B.K. and Uprit. S (2015). Studies on Chemical, Textural and Sensory Characteristics of Market and Laboratory PedaSamples Manufactured in Raipur City of Chhattisgarh. Orie J. Chem, 31(1): 231238.

Kulshrestha, S.B. (1990). Prevalence of enteropathogenic sero groups of E. coli in milk products samples from Bareilly and their multiple drug resistance. Indian $J$. Dairy Sci. 43: 337-338.

Kumar, V. and Sinha, R.N. (1989).Incidence of coliforms in indigenous milk products. Indian J. Dairy Sci.42: 579-580.

Londhe, G. and Pal, D. (2007). Development in shelf life extension of khoa based sweets an overview. Indian J. Dairy and Bio Sci. 18(2): 1-9.

Meneffee, S.G. and Overman, O.R. (1940) A semi-micro kjeldhal method for determination of total nitrogen in milk.J. Dairy Sci. 23(A): 143-147.

Patel, H. A., Salunke, Prafulla and Thakar, P. N. (2006). Chemical, microbiological, rheological and sensory characteristics of peda made by traditional and mechanized methods. J. Food Sci and Technol. 43: 196-199.

Patel, H.A. (1996). Comparative appraisal of quality of peda manufactured and sold in selected cities of Gujarat state. M.Sc. Thesis submitted to Department of Dairy Technology, SMC College of Dairy Science, GAU, Anand.

Prasad Rasane, Arvind and AlokJha. (2012). Textural and sensory characteristics of market samples of Peda manufactured in Varanasi city of India. J. Dairying, Foods \& H. S., 31(4): $239-243$.

Rajorhia, G.S. and Srinivasan, M.R. (1979). Technology of Khoa - A Review.Indian J. Dairy Sci. 32(3): 209-216.

Rajorhia, G.S. and Srinivasan, M.R. (1974). Physico-chemical changes during manufacturing of khoa, XIX Inter, Dairy Congr., IE, 216.

Reddy, C. R. (1985). Process Modification of production of khoa basd sweets. Ph. D. Thesis, Kurukshetra University, Kurukshetra.

Sharma Ganesh Dutt, Yadav, M.C, Singh, K.P and Singh, B.P. (2012). PhysicoChemical Quality of Milk Cake. Indian Res J. Ext Edu.1: 338-339.

Sharma, H. K.; Singhal, R. S.; Kulkarni, P. R. (2001). "Effect of packaging under vacuum or under nitrogen on the keeping quality of Danedar khoa". Int J. Dairy Technol. 54(3), 107-110.

Sharma, U.P. and Zariwala, J.T. (1978).Survey and quality of milk products in Bombay.J. Food Sci. Technol.15 (3): 118-121.

Steel, R. G. D. and Torrie J. H. (1980). Principles and Procedures of Statistics-a Biometrical Approach, $2^{\text {nd }}$ edn, New York: McGraw- Hill.

\section{How to cite this article:}

Srikanth Keerthi, Vyshnavi Manthani and Swarnalatha, G. 2018. Assessment of Quality of Peda Samples Sold in Kamareddy District - A Case Study. Int.J.Curr.Microbiol.App.Sci. 7(02): 14271434. doi: https://doi.org/10.20546/ijcmas.2018.702.172 